\title{
Evaluasi Capaian Peta Jalan JKN di Provinsi Bengkulu Studi Kasus Sectio Caesarea Tahun 2014 Sampai 2019
}

\section{Evaluation of JKN Road Map Achievement in Bengkulu Province Case Study of Sectio Caesarea 2014 to 2019}

\author{
Susilo Wulan', Jon Hendri Nurdan ${ }^{3}$, Yandrizal' $^{1}$, Muhamad Faozi Kurniawan ${ }^{2}$, Eko Rahman Setiawan 4 , \\ Dirhan $^{1}$ \\ ${ }^{1}$ Prodi Kesehatan Masyarakat, STIKES Tri Mandiri Sakti Bengkulu, Provinsi Bengkulu \\ 2Pusat Kebijakan dan Manajemen Kesehatan, Fakultas Kedokteran, Kesehatan Masyarakat dan Keperawatan, Universitas Gajah \\ Mada, DI Yogyakarta \\ 3Program Pascasarjana, Universitas Dehasen, Provinsi Bengkulu \\ ${ }^{4}$ Prodi Asuransi Kesehatan, Poltekkes Kemenkes Malang, Provinsi Jawa Timur
}

Korespondensi: Susilo Wulan

E-mail: wulan_susilo@yahoo.com

\begin{abstract}
Abstrak
Bengkulu adalah salah satu provinsi di Indonesia yang dalam 5 tahun terakhir sejak implementasi JKN tercatat mengalami peningkatan proporsi persalinan lewat operasi Caesar. Sementara, BPJS Kesehatan melaksanakan fungsi pembiayaan dalam pelayanan kesehatan JKN. Tujuan penelitian ini adalah mengevaluasi capaian sasaran equity kasus SC di Provinsi Bengkulu berdasarkan peta jalan JKN 2014-2019. Metode yang digunakan adalah mix method yakni kuantitatif dan kualitatif dengan cara analisis data JKN dan SUSENAS serta wawancara pihak BPJS Kesehatan dan Dinas Kesehatan. Hasil penelitian menunjukkan bahwa tata kelola program JKN di Provinsi Bengkulu sudah cukup baik dalam aspek capaian kepesertaan. Namun, pada pemerataan pelayanan dibutuhkan keterbukaan dan sinergitas program dan kebijakan antara pemerintah daerah dan BPJS Kesehatan. Layanan SC di Provinsi Bengkulu belum merata dan berkeadilan. Utilisasi layanan operasi caesar lebih banyak dinikmati oleh peserta JKN yang tinggal di Kota Bengkulu dan didominasi segmen kepesertaan mampu yakni PPU (39\%) dan PBPU (45\%). Pengawasan layanan SC perlu dilakukan secara cermat. Selain itu, pemenuhan kebijakan kompensasi pelayanan SC perlu diupayakan bagi wilayah faskes tidak memadai oleh BPJS Kesehatan maupun Pemerintah Provinsi Bengkulu.
\end{abstract}

Kata kunci: sectio caesarea, JKN, Bengkulu, Indonesia, pemerataan

\begin{abstract}
Bengkulu is one of the provinces in Indonesia where SC rate has increased significantly over the last five years after the implementation of JKN. Previous studies into SC trend in Indonesia indicate that both overutilization and underutilization of SC exist reflected inequality. SC is a public health concern since it absorbs a huge amount of JKN funds and is indicated to contribute to the BPJS deficit. This study evaluates the achievement of the SC case equity target in Bengkulu Province based on the 20142019 JKN roadmap. Combining qualitative and quantitative approaches, analyzing secondary data from the BPJS routine data and government survey (SUSENAS) as well as interview with Local government and BPJS staff. This study found that despite the increase in coverage of JKN memberships, gap exists in the provision of health professionals, doctors and obstetrician distribution likely affected the utilization of SC. Currently, SC is enjoyed mostly by women residing in Bengkulu city and dominated by PPU and PBPU segment, which are 39 and 45\% respectively. Improved monitoring and realization of compensation policy to provide equal distribution of doctors and obstetricians either by BPJS or local government.
\end{abstract}

Keyword: sectio caesarean, JKN, equity, Bengkulu, Indonesia 


\section{Pendahuluan}

Dalam rangka mewujudkan akses ke pelayanan kesehatan yang adil dan merata, Pemerintah Indonesia mengintegrasikan program asuransi kesehatan sebelumnya ke dalam satu wadah bernama JKN (Jaminan Kesehatan Nasional). Penyelenggaraan program JKN mengintegrasikan fungsi pembiayaan pelayanan kesehatan dan fungsi penyelenggaraan pelayanan kesehatan bagi pelayanan kesehatan perorangan. JKN adalah salah satu program jaminan sosial dalam sistem jaminan sosial nasional yang dikelola oleh lembaga baru yakni BPJS Kesehatan (Putri, 2015).

Implementasi program JKN sejak 2014 2019 selalu mencatat angka defisit yang jumlahnya terus meningkat. Penyebab defisit itu ialah jumlah iuran yang tidak sesuai perhitungan standar aktuaria, adverse selection, dan tata kelola yang dinilai masih belum baik (Trisnantoro \& et.al, 2019). Selain itu, beberapa layanan penyakit kronis dan prosedur menjadi penyebab defisit BPJS Kesehatan. Operasi caesar merupakan salah satu yang menelan pembiayaan besar dalam program JKN. Laporan BPJS Kesehatan tahun 2017 menunjukkan bahwa operasi pembedahan caesar ringan menduduki peringkat pertama klaim BPJS dengan jumlah kasus sebanyak 548.978 kasus dengan total pembiayaan sebanyak Rp3.012.201.951.403 (BPJS Kesehatan, 2018).

Dalam kurun waktu 50 tahun terakhir di Indonesia, terjadi peningkatan signifikan tindakan operasi caesar. Permintaan sectio caesarea (SC) pada tahun 70-an, hanya sebesar $5 \%$, namun saat ini lebih dari 50\% ibu hamil menginginkan operasi caesar (Ayuningtyas \& et.al, 2018). Rata-rata persentase persalinan tahun 2015 sampai 2019 di seluruh fasilitas kesehatan, yang melakukan SC sebanyak 35\%, dan 65\% persalinan normal, jauh melebihi standar minimal $10-15 \%$ yang ditetapkan WHO (BPJS Kesehatan, 2020).
Kepemilikan asuransi kesehatan menjadi faktor utama pemilihan persalinan secara caesar dibandingkan dengan persalinan normal. Pada tahun 2019, misalnya total pembiayaan JKN untuk persalinan mencapai 23, 6 triliun, $80 \%$ dari total pembiayaan persalinan tersebut sebesar Rp18,7 triliun adalah untuk prosedur SC, sedangkan untuk persalinan normal hanya Rp4,8 triliun (BPJS Kesehatan, 2020). Hal ini sejalan dengan penelitian Widyajanti di mana ibu hamil dengan kepemilikan asuransi 1,12 kali lebih memilih SC dibandingkan dengan yang tidak memiliki asuransi (Widjayanti \& Sjaaf, 2020). Data-data tersebut menunjukkan adanya kemungkinan pemakaian tindakan yang tidak perlu.

Selain persoalan adanya indikasi penggunaan layanan operasi caesar yang tidak diperlukan, riset juga menunjukkan bahwa adanya kesenjangan penggunaan layanan operasi caesar dilihat dari karakteristik sosial demografis. Analisa seri Survei Demografi dan Kesehatan Indonesia (SDKI) tahun 1987 sampai 2017 di Indonesia menemukan bahwa yang paling banyak menggunakan layanan operasi caesar adalah ibu hamil yang tinggal di wilayah perkotaan, berpenghasilan, dan berpendidikan lebih tinggi (Zahroh, 2020). Hal ini mengindikasikan adanya persoalan inequality dalam hal pemakaian operasi caesar di Indonesia, di mana golongan yang mungkin membutuhkan layanan tidak dapat menikmati layanan karena keterbatasan ekonomi dan hambatan geografis. Inequality in Health yang dimaksud merupakan konsep normatif dan merujuk pada ketidakseimbangan yang dianggap tidak adil sebagai hasil dari berbagai proses sosial, dimana salah satu faktor penyebabnya adalah factor social ekonomi seperti distribusi anggaran belanja pemerintah dan pendapatan serta sumber daya lain di masyarakat. 
Bengkulu adalah salah satu provinsi di Indonesia yang dalam 5 tahun terakhir sejak implementasi JKN tercatat mengalami peningkatan proporsi persalinan lewat operasi $\mathrm{SC}$, baik di rumah sakit milik pemerintah maupun rumah sakit swasta. Jumlah kasus yang besar ini tentu akan membawa konsekuensi dalam pendanaan kesehatan yang relatif besar dibandingkan persalinan normal. Jika jumlah kasus SC meningkat, beban BPJS Kesehatan dalam pembiayaan kesehatan program JKN juga akan meningkat. Situasi ini juga belum mencerminkan konsep pembelian yang strategis dalam layanan JKN.

Fungsi pembiayaan pelayanan kesehatan JKN salah satunya dilaksanakan oleh BPJS Kesehatan. BPJS Kesehatan secara aktif mengumpulkan iuran dari peserta, kemudian menggabungkan seluruh iuran peserta (pooling), dan mengelolanya (purchasing and investing) dengan cermat, hati-hati, transparan, efisien, dan efektif untuk sebesar-besarnya kepentingan perlindungan kesehatan peserta (Putri, 2015) .

Diskusi yang berlangsung selama penyusunan kebijakan dan pelaksanaan, program JKN adalah upaya mereformasi sistem kesehatan nasional. Sistem kepesertaan yang wajib dan manfaat yang seragam secara teori akan mewujudkan prinsip keadilan sosial. Namun, defisit yang terus menerus terjadi setiap tahun mengindikasi adanya tata kelola yang perlu dibenahi.

Sustainabilitas program JKN menuntut langkah strategis dalam pemulihan sistem kesehatan yang berkeadilan dan resiliensi terhadap bencana baik alam maupun non alam. Kajian ini bertujuan untuk menganalisis capaian 8 sasaran peta jalan JKN yang telah disusun pemerintah 2012-2019 dalam aspek yakni tata kelola dan ekuitas layanan SC. Kajian ini diharapkan dapat menjadi sumbangsih pemikiran pemulihan sistem kesehatan nasional pasca pandemi.

\section{Gambar 1. Diagram Defisit Program JKN}
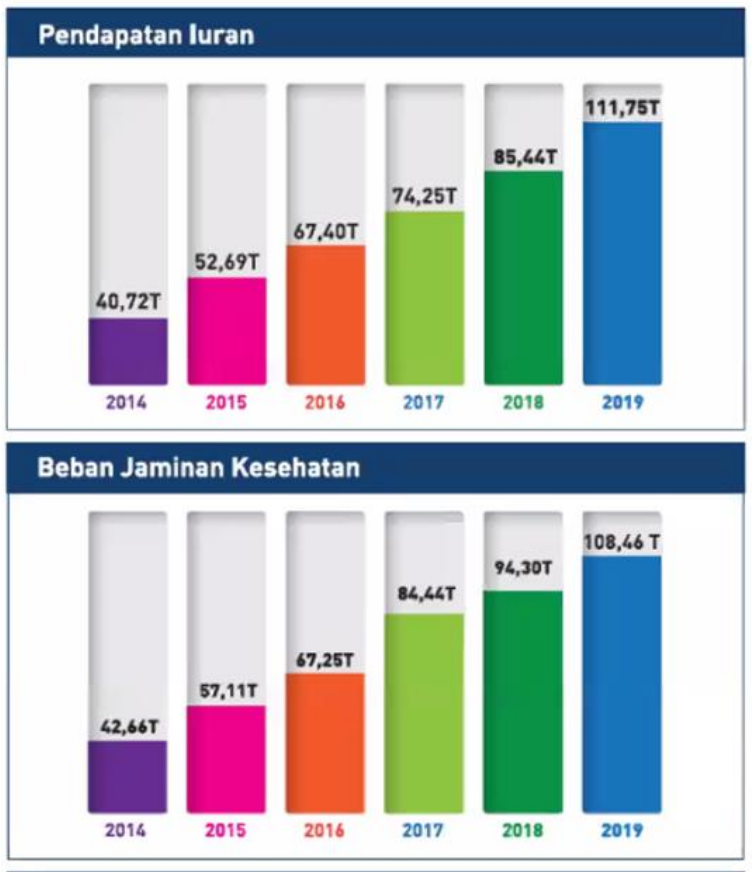

Sumber: Laporan BPJS Kesehatan 2019 dalam Thabrany 


\section{Metode Penelitian}

Penelitian ini merupakan evaluasi pencapaian sasaran peta jalan JKN 2019 menggunakan metode deskriptif dengan pendekatan kuantitatif dan kualitatif. Dengan menggunakan studi kasus SC di Provinsi Bengkulu untuk menjawab pertanyaan kunci apakah implementasi program JKN telah dikelola dengan baik dan sudah mampu mencapai sasarannya mewujudkan pemerataan layanan kesehatan yang berkeadilan. Sumber data dalam penelitian yaitu data sekunder yang diolah dari data rutin BPJS, DJSN, dan riset kesehatan yang dilakukan oleh Pemerintah yang dimuat dalam dashboard kesehatan (DaSK), meliputi data sample BPJS Kesehatan, data SUSENAS dan RISKESDAS.

Analisis data dalam penelitian ini dilakukan melalui tiga kegiatan yaitu reduksi data, penyajian data, dan penarikan kesimpulan. Data kuantitatif diperoleh dari data sekunder berupa data sample BPJS 2014 - 2018 khususnya data persalinan di Provinsi Bengkulu yang dianalisis berdasarkan kelas perawatan, segmen kepesertaan, rujukan dan jenis tindakan SC. Data disajikan secara deskriptif dalam bentuk angka absolut dan proporsi. Aspek ideal yang dijadikan dasar evaluasi adalah terkait aspek kepesertaan, utilisasi, paket manfaat, dan supply side layanan kesehatan untuk menjawab topik tata kelola dan equity. Data kualitatif dikumpulkan dengan cara indepth interview kepada para pemangku kepentingan di Dinas Kesehatan Kabupaten Bengkulu Selatan, Dinas Kesehatan Kota Bengkulu, dan Dinas Kesehatan Provinsi Bengkulu. Dasar pertimbangan penentuan sample adalah pertimbangan representatif dengan quota sampling ditetapkan sebagai perkiraan relatif yang memadai dan dapat mencerminkan populasi sesuai dengan tujuan penelitian. Data Kuantitatif berupa rekaman hasil wawancara dituliskan dalam transkrip wawancara kemudian dianalisis dengan pendekatan analisa isi (content analysis) dengan mengevaluasi jawaban responden berdasarkan topik evaluasi yaitu ekuitas, dan tata kelola.

Tabel 1. Peta Jalan Menuju JKN 2014 - 2019

\begin{tabular}{cl}
\hline No & \multicolumn{1}{c}{ Sasaran 1 Januari 2014 } \\
\hline 1. & BPJS Kesehatan mulai beroperasi. \\
2. & BPJS Kesehatan mengelola jaminan kesehatan \\
& setidaknya bagi 121,6 juta peserta (sekitar 50 juta \\
& masih dikelola Badan lain). \\
3. & Paket manfaat medis yang dijamin adalah seluruh \\
& pengobatan untuk seluruh penyakit. Namun, masih \\
& ada perbedaan kelas perawatan di rumah sakit bagi \\
& yang mengiur sendiri dan bagi Penerima Bantuan \\
Iuran (PBI) yang iurannya dibayarkan oleh \\
Pemerintah.
\end{tabular}

4. Rencana Aksi Pengembangan fasilitas kesehatan tersusun dan mulai dilaksanakan

5. Seluruh peraturan pelaksanaan (PP, Perpres, Peraturan Menteri, dan Peraturan BPJS) yang merupakan turunan UU SJSN dan UU BPJS telah diundangkan dan diterbitkan
BPJS Kesehatan beroperasi dengan baik.

Seluruh penduduk Indonesia (yang pada 2019 diperkirakan sekitar 257,5 juta jiwa) mendapat jaminan kesehatan melalui BPJS Kesehatan.

Paket manfaat medis dan non medis (kelas perawatan) sudah sama, tidak ada perbedaan, untuk mewujudkan keadilan sosial bagi seluruh rakyat.

Jumlah dan sebaran fasilitas pelayanan kesehatan (termasuk tenaga dan alat-alat) sudah memadai untuk menjamin seluruh penduduk memenuhi kebutuhan medis mereka.

Semua peraturan pelaksanaan telah disesuaikan secara berkala untuk menjamin kualitas layanan yang memadai dengan harga keekonomian yang layak 


\begin{tabular}{cll}
\hline No & \multicolumn{1}{c}{ Sasaran 1 Januari 2014 } & \multicolumn{1}{c}{ Sasaran 2019 } \\
\hline 6. & $\begin{array}{l}\text { Paling sedikit 75\% peserta menyatakan puas, baik } \\
\text { dalam layanan di BPJS maupun dalam layanan di } \\
\text { fasilitas kesehatan yang dikontrak BPJS }\end{array}$ & $\begin{array}{l}\text { Paling sedikit 85\% peserta menyatakan puas, baik dalam } \\
\text { layanan di BPJS maupun dalam layanan di fasilitas } \\
\text { kesehatan yang dikontrak BPJS }\end{array}$ \\
7. $\begin{array}{l}\text { Paling sedikit 65\% tenaga dan fasilitas kesehatan } \\
\text { menyatakan puas atau mendapat pembayaran yang }\end{array}$ & $\begin{array}{l}\text { Paling sedikit 80\% tenaga dan fasilitas kesehatan } \\
\text { menyatakan puas atau mendapat pembayaran yang layak } \\
\text { layak dari BPJS } \\
\text { BPJS dikelola secara terbuka, efisien, dan } \\
\text { akuntabel }\end{array}$ & $\begin{array}{l}\text { BPJS dikelola secara terbuka, efisien, dan akuntabel } \\
\text { 8. }\end{array}$ \\
\hline
\end{tabular}

Sumber: Dokumen Peta Jalan Menuju JKN 2012-2019

\section{Hasil Penelitian}

Kepesertaan JKN di Provinsi Bengkulu pada tahun 2021 menurut Grafik 1 menunjukkan bahwa masih ada $23,1 \%$ atau sekitar 465.867 penduduk yang belum terdaftar dalam program JKN. Segmen yang memiliki proporsi paling kecil adalah Bukan Pekerja (BP), yakni 1.4\% atau 21.225 jiwa. Sedangkan, segmen kepesertaan terbanyak didominasi oleh PBI Pusat, yaitu sebanyak 735. 564 jiwa. Berikut pernyataan Dinas Kesehatan dalam wawancara terkait kepesertaan JKN di wilayahnya.
"Data jumlah peserta JKN di Provinsi Bengkulu 1.519.408 tersebar di $10 \mathrm{kab} / \mathrm{kota}$. Cakupan tertinggi ada di kabupaten Bengkulu selatan 93\% dan cakupan terendah di Kabupaten Rejang Lebong 64\%. Bengkulu selatan hampir mendekati UHC (95 persen untuk batasan UHC), namun adanya kenaikan premi di akhir tahun lalu, menyebabkan dana tidak cukup, sehingga Bengkulu selatan belum jadi UHC." (Dinas Kesehatan Provinsi Bengkulu)

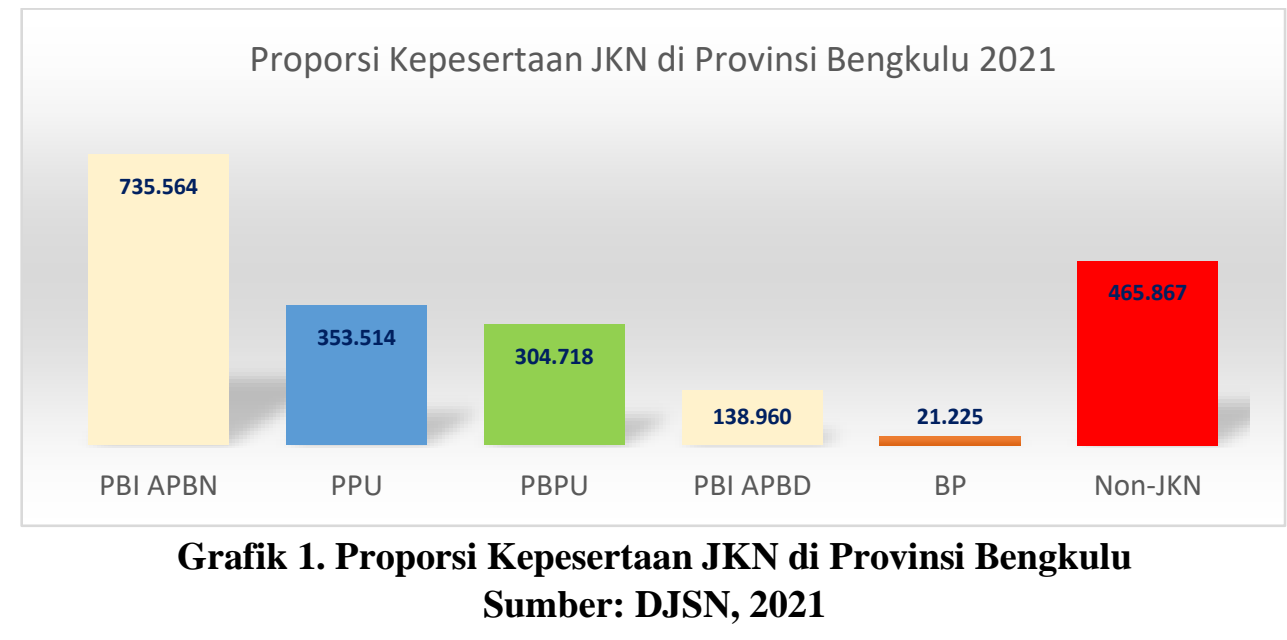

Grafik 2 memperlihatkan bahwa adanya peningkatan jumlah rumah tangga miskin yang bergabung dalam program JKN. Di awal implementasi JKN rata-rata lebih dari $80 \%$ kelompok rumah tangga, 20\% termiskin yang tidak terdaftar dalam program JKN, di tahun 2018 proporsi ini menurun, tetapi masih ada beberapa kabupaten yang lebih dari 40\%-20\% kelompok termiskinnya belum tergabung dalam JKN. Selain dukungan kebijakan/peraturan dalam cakupan kepesertaan JKN. Pemerintah Provinsi Bengkulu juga memberikan biaya tambahan bagi penduduknya yang harus dirujukan menuju 
fasilitas kesehatan di luar Provinsi Bengkulu, berikut kuotasi wawancara:

"Pemda kami dalam mendukung JKN ini telah membantu memberi subsidi yaitu biaya hidup dan ongkos transportasi bagi peserta JKN yang harus dirujuk ke RS Tipe A..." (Dinas Kesehatan Kab. Bengkulu Selatan)

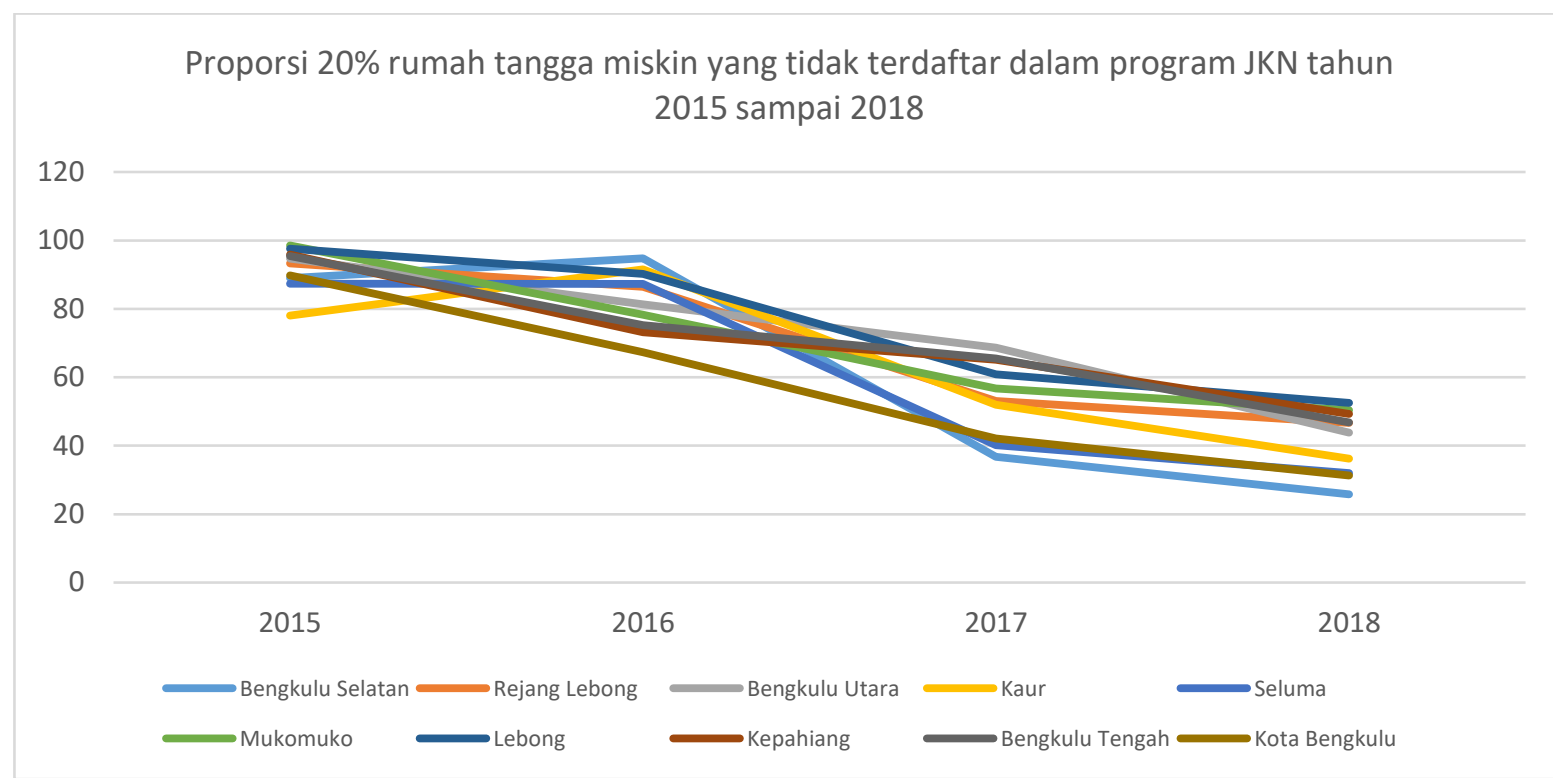

Grafik 2. Proporsi 20\% rumah tangga termiskin yang tidak terdaftar dalam program JKN (Susenas, 2018)

Pemerintah Provinsi Bengkulu menganggarkan dana Rp 17,6 miliar, atau sekitar $37,5 \%$ untuk subsidi peserta JKN dari kalangan keluarga tidak mampu. Dana tersebut berasal dari penerimaan pajak daerah dari pajak rokok sesuai Perpres No. 82 Tahun 2018 tentang JKN, dan Permenkeu No 128/PMK.07/2018 tentang tata cara pemotongan pajak rokok untuk kontribusi JKN. Berikut kuotasi wawancara:

"Penerima program jamkesprop 2020 adalah peserta mandiri kelas 3 yang menunggak iuran. Kita hanya mengaktifkan kembali peserta sesuai dengan anggaran pajak rokok provinsi Bengkulu yang tersedia yaitu sekitar 23.000 peserta...." (Dinkes Prov Bengkulu)
Ukuran keberhasilan UHC tidak hanya diukur dari cakupan kepesertaan, WHO merumuskan tiga dimensi capaian UHC, yakni: 1) seberapa besar persentase penduduk yang dijamin; 2) seberapa lengkap pelayanan yang dijamin; 3) seberapa besar persentase proporsi biaya langsung yang masih ditanggung oleh penduduk. Uraian utilisasi dan pembiayaan kasus SC yang akan disajikan selanjutnya akan memberikan gambaran pemanfaatan layanan SC antar segmen peserta dan antar wilayah di Provinsi Bengkulu.

Dari kasus persalinan di RS Provinsi Bengkulu $64 \%$ nya adalah SC. Ada $85 \%$ tindakan SC dilakukan atas dasar rujukan. Persentase tertinggi tindakan SC adalah jenis Operasi Pembedahan Caesar Ringan (94\%) dengan rujukan dari berbagai faskes, baik FKTP maupun Rumah Sakit tipe D dan C. 
Diagram Klaim Persalinan dan Proporsi Persalinan berdasarkan Rujukan di Provinsi Bengkulu

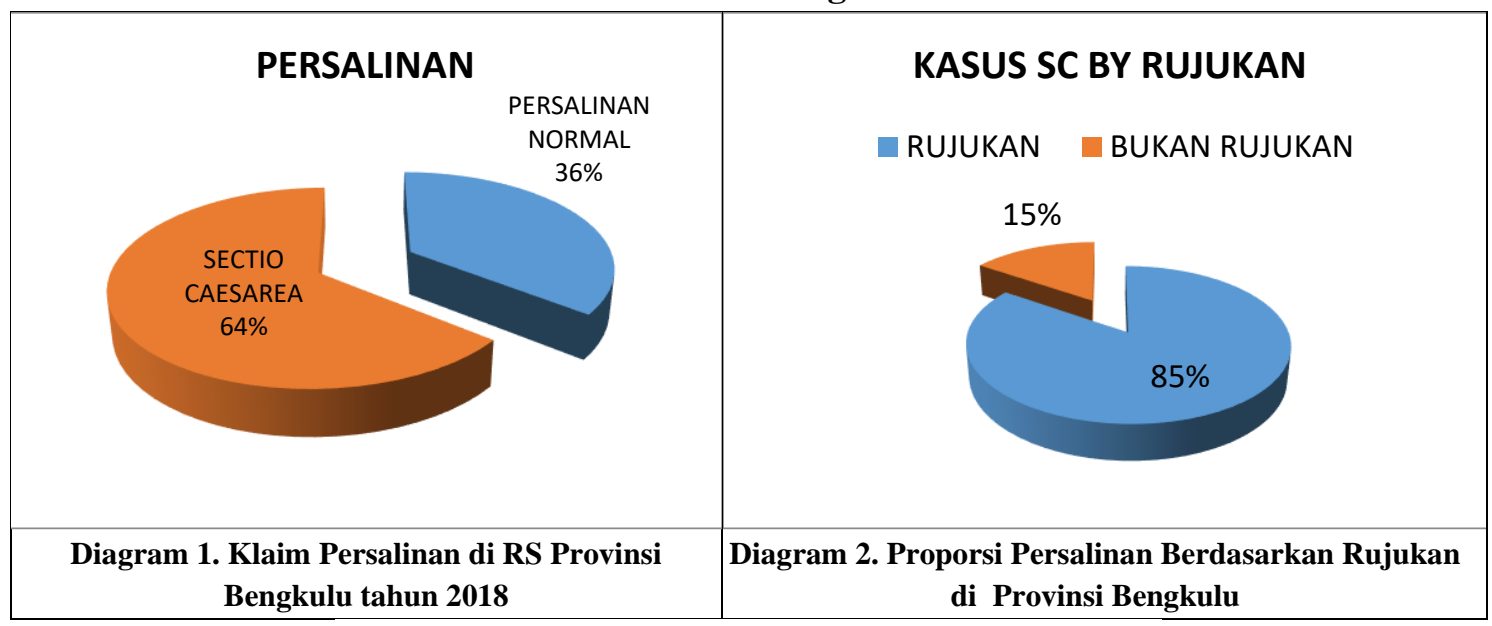

Sumber: (DaSK, 2021) Data Sampel BPJS 2015-2018

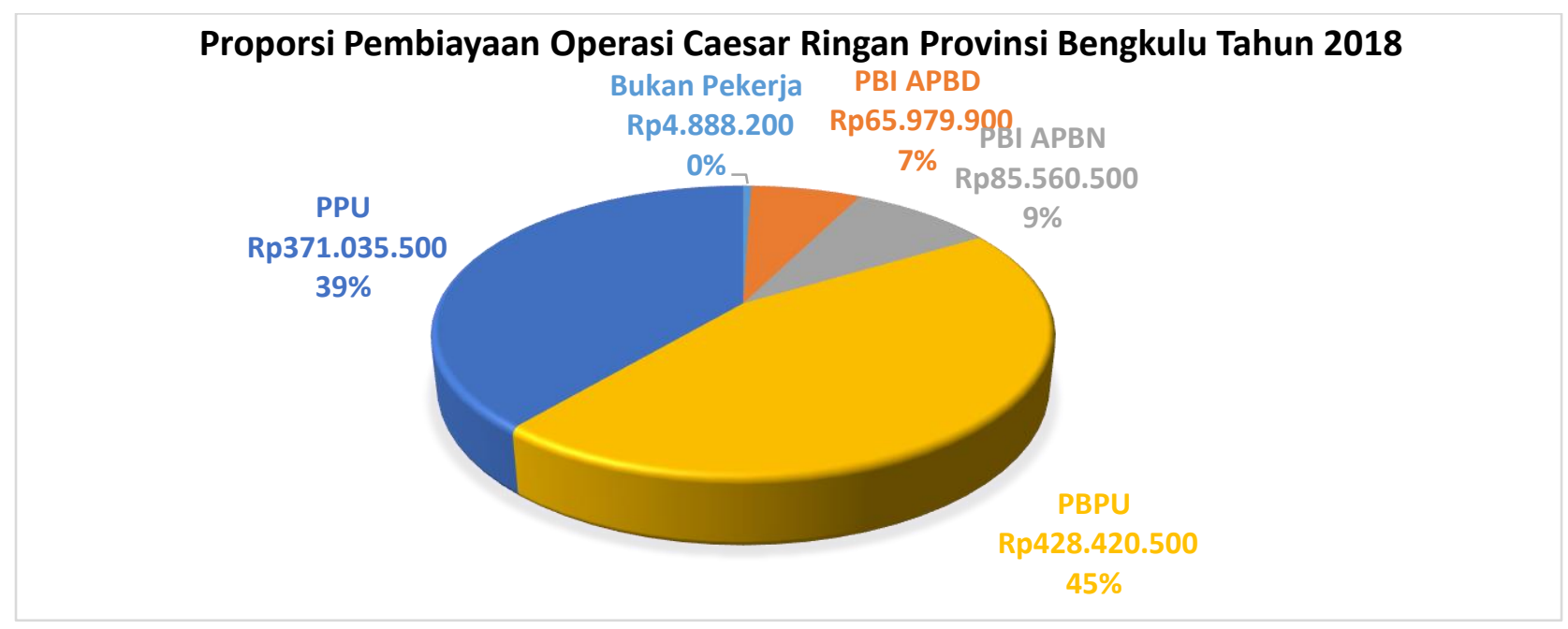

Diagram 3. Proporsi Pembiayaan SC Ringan di Provinsi Bengkulu

Diagram 3 memberikan gambaran mengenai tindakan operasi SC ringan di Provinsi Bengkulu tahun 2018. Utilisasi layanan operasi caesar lebih banyak dinikmati segmen Peserta Penerima Upah (PPU) sebanyak 39\%, dan Peserta Bukan Penerima Upah (PBPU) sebanyak 45\% dengan total pembiayaan untuk operasi caesar ringan sebesar Rp371.035.500 dan Rp428.420.500. Jumlah ini 5 kali lipat lebih besar dibandingkan dengan total pembiayaan operasi ringan pada segmen Peserta Penerima Bantuan Iuran (PBI) baik PBI APBN (Anggaran Pendapatan dan Belanja Negara) maupun PBI APBD (Anggaran Pendapatan dan Belanja Daerah). 


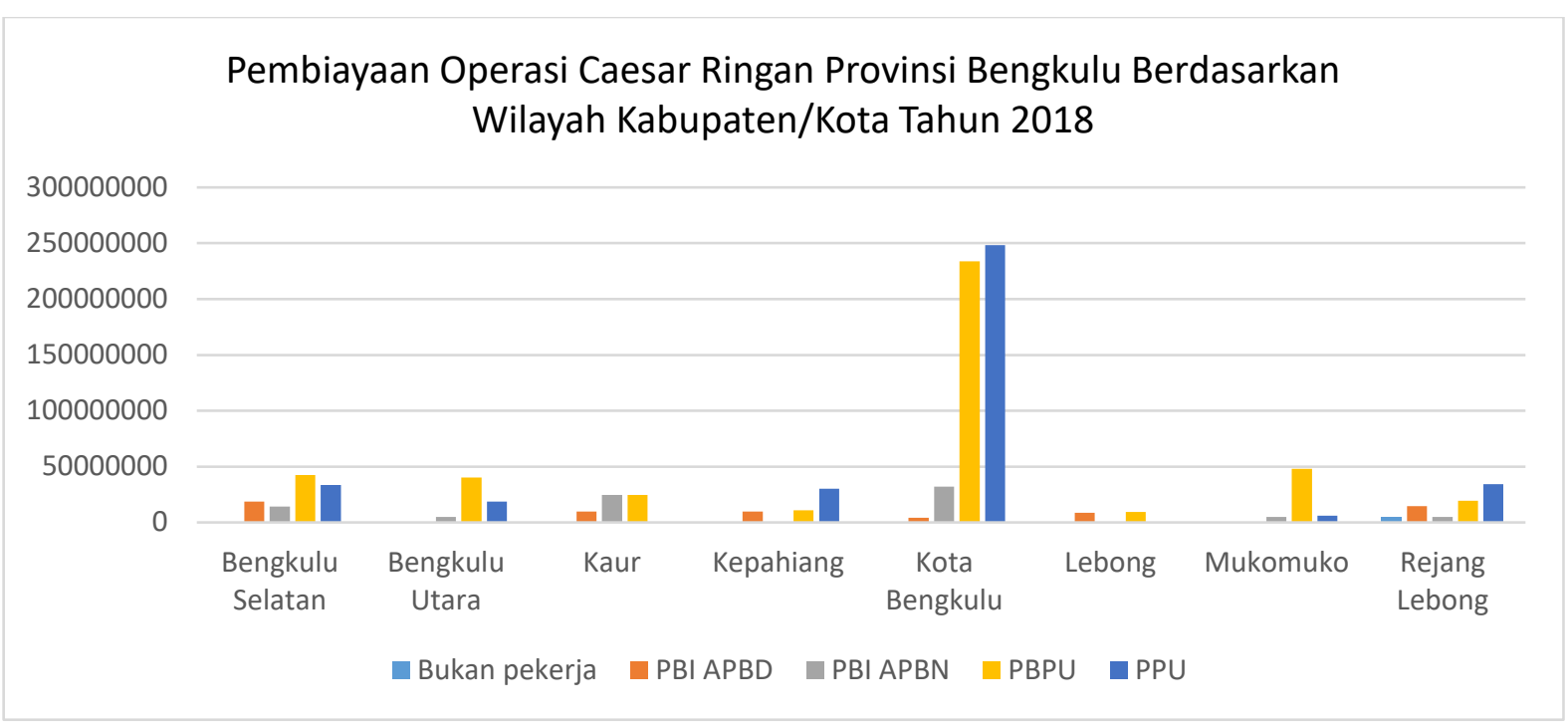

Grafik 3. Pembiayaan Operasi Caesar Ringan Provinsi Bengkulu tahun 2018

Grafik 3 memberikan gambaran mengenai besaran pembiayaan operasi SC ringan di Provinsi Bengkulu tahun 2018. Utilisasi layanan operasi caesar lebih banyak dinikmati oleh penduduk yang tinggal di kota Bengkulu dengan kepesertaan PPU dan PBPU dibandingkan dengan 7 Kabupaten lainnya di wilayah Provinsi Bengkulu. Berdasarkan diagnosis primer diketahui bahwa Faktor risiko utama penyebab tingginya kasus SC ringan di Provinsi Bengkulu dikarenakan delivery by elective caesarean section, maternal care due to uterine scar from previous surgery dan premature rupture of membranes, onset of labour within 24 hours.
Grafik 4 memberikan gambaran mengenai tindakan operasi caesar sedang di Provinsi Bengkulu tahun 2018. Utilisasi layanan operasi caesar sedang menunjukkan data yang sama seperti operasi caesar ringan, yakni lebih banyak dinikmati oleh penduduk yang tinggal di kota Bengkulu dari segmen PPU dan PBPU. Utilisasi SC sedang pada segmen PBPU juga terjadi di Kabupaten Bengkulu Selatan dan Kaur. Dalam kasus SC Sedang akses peserta segmen PBI APBN terdapat di Kabupaten Bengkulu Utara dan Kaur.

\section{Pembiayaan Operasi Caesar Sedang Provinsi Bengkulu Berdasarkan}

Kabupaten/Kota Tahun 2018

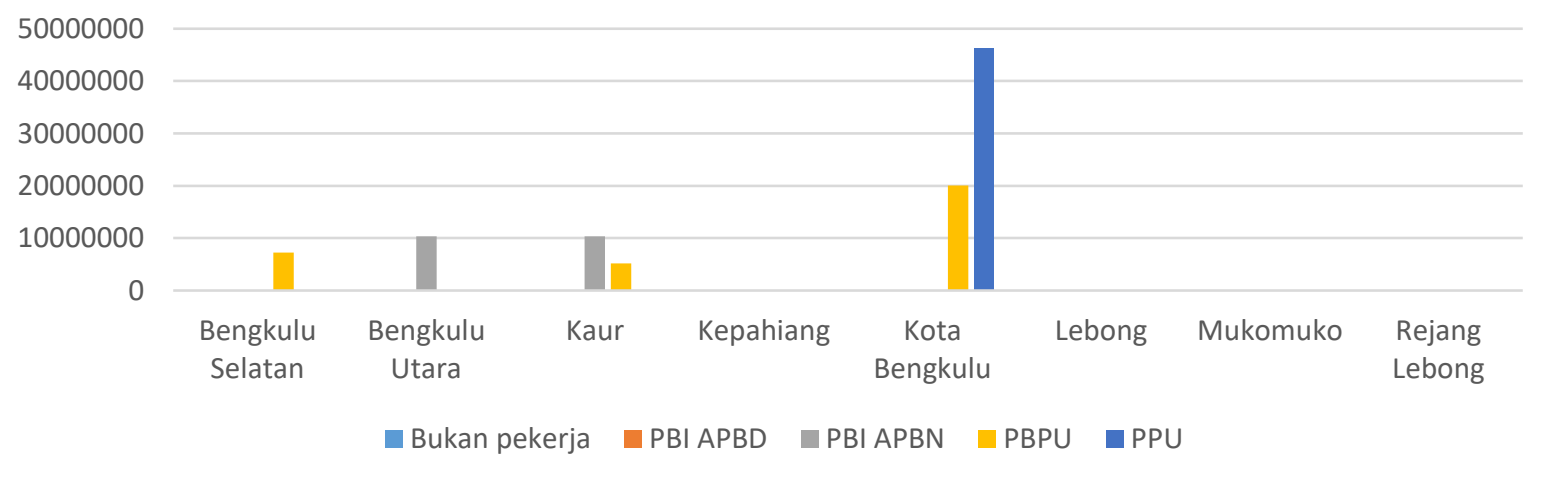

Grafik.4 Pembiayaan Operasi Caesar Sedang 
Diagram 4 memberikan gambaran mengenai tindakan operasi caesar sedang di Provinsi Bengkulu tahun 2018. Utilisasi layanan operasi caesar sedang pada segmen PPU mencapai Rp 46. 428.000,00 atau 47\% dari total pembiayaan operasi caesar sedang di provinsi Bengkulu dan hanya terdapat di kota Bengkulu. Sementara hanya $21 \%$ dari total pembiayaan untuk operasi caesar sedang yang digunakan oleh segmen sasaran PBI APBN.

Diagram 4. Proporsi Pembiayaan Operasi Caesar Sedang Provinsi Bengkulu Berdasarkan Segmen Peserta Tahun 2018

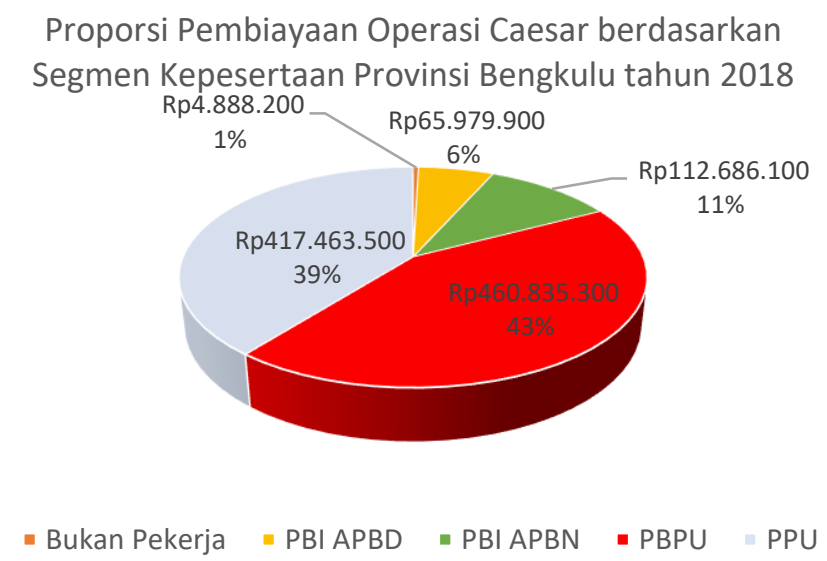

Diagram 5 Proporsi Pembiayaan Operasi Caesar berdasarkan Segmen Kepesertaan Provinsi Bengkulu tahun 2018

Diagram 5 di atas menunjukkan bahwa layanan operasi caesar lebih banyak dinikmati (80\%) oleh kelompok PBPU dan PPU dibandingkan dengan kelompok kepesertaan JKN yang lainnya. Bahkan hanya $17 \%$ proporsi kelompok PBI APBN dan APBD yang menikmati layanan operasi caesar. Data pembiayaan pelayanan kesehatan secara segmentasi tidak berhasil di dapat karena OPDOPD di Provinsi Bengkulu tidak memilikinya.

“...Sejauh ini data-data yang terkait dengan peserta PPU, bukan pekerja, PBPU tidak 
disampaikan ke dinas, tetapi hanya yang peserta PBI baik APBD/APBN..." (Dinkes

Kab. Bengkulu Selatan)

Sementara, Pemerintah Provinsi Bengkulu baru mengalokasi 3,03\% untuk belanja kesehatan atau mandatory. Di mana persentase alokasi tersebut belum memenuhi perintah undangundang (Kemenkeu, 2019). Investasi utama di Provinsi Bengkulu, yaitu industri sektor kelistrikan, perkebunan, perdagangan besar hasil pertanian, dan perhotelan. Berdasarkan analisis fiskal pemerintah Provinsi Bengkulu belum mampu membiayai belanja daerah secara mandiri

Tabel 2. Distribusi Tenaga Kesehatan di Provinsi Bengkulu

\begin{tabular}{lccccc}
\hline & Bidan & $\begin{array}{l}\text { Dokter } \\
\text { Umum }\end{array}$ & $\begin{array}{l}\text { Rasio dokter } \\
\text { per 100.000 } \\
\text { penduduk }\end{array}$ & $\begin{array}{l}\text { Spesialis } \\
\text { Kandungan }\end{array}$ & $\begin{array}{l}\text { Rasio spesialis } \\
\text { kandungan per } \\
\mathbf{1 0 0 . 0 0 0} \text { penduduk }\end{array}$ \\
\hline Muko Muko & 132 & 14 & 8,45 & 4 & 2,11 \\
Bengkulu Selatan & 47 & 16 & 9,58 & 4 & 2,56 \\
Rejang Lebong & 81 & 18 & 6,93 & 3 & 1,16 \\
Bengkulu Utara & 92 & 19 & 7,59 & 2 & 0,66 \\
Kaur & 57 & 15 & 12,54 & 3 & 2,51 \\
Seluma & 33 & 6 & 3,13 & 1 & 0,52 \\
Lebong & 31 & 12 & 10,49 & 0 & 0 \\
Kepahiang & 66 & 12 & 8,84 & 2 & 1,47 \\
Bengkulu Tengah & 33 & 8 & 7,1 & 0 & 0 \\
Kota Bengkulu & 271 & 121 & 30,7 & 31 & 8,28 \\
Total & 843 & 241 & & 50 & \\
\hline
\end{tabular}

Sumber: DaSK SDM

Berdasarkan tabel. 2 diatas diketahui bahwa terdapat tiga kabupaten/kota yang tidak memiliki dokter spesialis kandungan. Ada dua permasalahan utama yaitu sebaran dokter spesialis kandungan juga tidak merata antar kabupaten/kota, di mana jumlah dokter ahli kebidanan dan kandungan lebih banyak di Kota Bengkulu dengan rasio 8,28 per 100.000 penduduk. Yang kedua, di semua wilayah kabupaten di Bengkulu, tidak ada satu kabupaten/ kota yang memenuhi standar pedoman Kemenkes dan WHO yaitu 9 per 100.000 penduduk.

\section{Pembahasan}

Penelitian ini telah menunjukkan bahwa masih ada kesenjangan kepesertaan JKN antar kabupaten/kota di Provinsi Bengkulu. Dari sisi cakupan kepesertaan, ada sebanyak $23,1 \%$ atau 465.867 penduduk yang belum terdaftar dalam program JKN ini perlu segera di validasi data kependudukannya oleh dinas terkait agar strategi peningkatan kepesertaan dapat dilakukan. Upaya Pemerintah Provinsi Bengkulu untuk meningkatkan cakupan kepesertaan yaitu dengan pemetaan Kab/Kota atas capaian kepesertaan yang belum optimal, kemudian melakukan subsidi silang atau sharing pembayaran peserta antara Kab/Kota yang bersangkutan dengan Provinsi. Hal ini didasarkan pada amanat Pasal 101 dan 102 Perpres 82 Tahun 2018 tentang JKN, yaitu mendanai program jaminan kesehatan dan 
Integrasi program jamkesda ke dalam JKN yang dilaksanakan oleh BPJS Kesehatan.

WHO HEAT (World Health Organization

Health Equity Assessment Toolkit) menggunakan lima dimensi dalam mengukur inequality yaitu status sosial ekonomi, pendidikan, tempat tinggal (urban vs rural), jenis kelamin, dan regional. Utilisasi SC hampir 5 kali lebih sering pada kelompok terkaya dibandingkan dengan kelompok termiskin di Negara Berkembang (Delport, 2019). Hal ini juga sejalan dengan temuan studi sebelumnya bahwa kondisi sosial ekonomi, tingkat pendidikan, dan tempat tinggal memiliki hubungan linear positif dengan askes ke pelayanan kesehatan (Nababan, Hasan, Marthias, \& et.al, 2018)

Data utilisasi dan pembiayaan SC di Provinsi Bengkulu menunjukkan bahwa penduduk ibukota provinsi atau kotamadya memiliki akses lebih besar untuk terdaftar dalam program JKN dibandingkan dengan penduduk wilayah kabupaten. Akses merupakan kesempatan untuk mendapatkan pelayanan kesehatan yang tepat, sesuai dengan kebutuhan. Komponen yang mempengaruhi akses adalah ketersedian dokter serta kemudahan menghubungi dokter. Variasi yang terjadi dalam akses pelayanan kesehatan, terdiri atas availability, quality, cost, dan information.

Dalam konteks ini terjadi inequity dalam akses SC di Provinsi Bengkulu. Disparitas terjadi ketika kelompok tertentu dalam masyarakat dapat menemukan pelayanan kesehatan dengan mudah, memperoleh perawatan lebih tepat dengan pengeluaran uang lebih sedikit, serta memperoleh informasi yang cukup, dibandingkan kelompok lain yang memiliki kebutuhan kesehatan yang sama. Orang yang tinggal di perkotaan memiliki kecenderungan lebih besar untuk mengakses fasilitas kesehatan dibandingkan kelompok miskin (Nababan, Hasan, Marthias, \& et.al, 2018). Hal ini tentu didukung dari aspek demand side maupun supply side (Mishra, Veerapandian,
\& Choudhary, 2021). Harus dipahami akan selalu ada variasi dalam penyediaan pelayanan kesehatan yang tidak bisa didistribusikan secara merata antar daerah maupun antar kelompok. Dalam perkembangannya akan terjadi ketidakseimbangan dalam program kesehatan ketika dibandingkan antara urban dan suburban. Hal ini dikarenakan, sebagian besar rumah sakit umum khususnya rs tersier Kota, serta RS ini memperoleh dukungan lebih, termasuk fiskal dan kebijakan, dibandingkan yang RS yang di daerah (Dong, Xu, Sun, Zhang, \& Wang, 2021).

Peserta yang tinggal di Kota Bengkulu lebih banyak mengakses pelayanan SC dan menyerap pembiayaan yang besar dibandingkan kabupaten lainnya ( Kaur, Bengkulu Selatan, Kepahiang, Rejang Lebong, Lebong, Bengkulu Utara dan Muko-Muko). Tingginya jumlah utilisasi dan pembiayaan SC di Kota Bengkulu salah satunya adalah karena menerima rujukan dari Kabupaten Bengkulu Tengah dan Seluma. Dua Kabupaten ini selain berbatasan langsung dengan Kota Bengkulu, juga tidak memiliki dokter obgyn serta memiliki RS tipe D, sehingga kasus persalinan SC yang tidak mampu ditangani di dua Kabupaten ini dirujuk ke RS di Kota Bengkulu.

Indikasi inequity juga tercermin dari rendahnya akses layanan operasi caesar bagi kelompok termiskin dalam hal ini PBI. Sementara segmen PPU dan PBPU lebih banyak mengakses pelayan SC (78\%) dibandingkan kelompok PBI (miskin/tidak mampu). Segmen PPU dan PBPU merupakan kelompok yang dianggap mampu karena iuran atau premi bulanan dibayarkan secara mandiri oleh peserta, berbeda dengan PBI yang merupakan kelompok tidak mampu sehingga iuran atau preminya dibayarkan oleh Negara. Oleh karena itu, Pemerintah Provinsi Bengkulu dan BPJS Kesehatan perlu mengimplementasi agile governance untuk memenuhi dimensi lain dalam UHC (Luna, Kruchten, \& Moura, 2015). 
Rasio dokter baik umum maupun dokter spesialis obgyn di Provinsi Bengkulu menunjukkan ketimpangan antar kabupaten/kota. Hanya terdapat $4 \mathrm{Kab} /$ Kota yang jumlah dokternya terdistribusi, sementara Kabupaten Seluma, Kabupaten Bengkulu Tengah dan Kabupaten Bengkulu Utara masih terjadi ketimpangan jumlah dokter umum. Keterbatasan serta distribusi bidan, dokter umum maupun dokter spesialis kandungan yang tidak merata antar kab/kota di provinsi bengkulu menyebabkan utilisasi persalinan SC di kota lebih tinggi daripada di kabupaten. Menurut riset (Dong, Xu, Sun, Zhang , \& Wang, 2021) dokter, bidan dan tenaga kesehatan lainnya lebih menyukai bekerja di institusi yang besar di Kota yang memberikan keuntungan yang relatif besar dalam bentuk gaji maupun pengembangan karir.

Selain terbatasnya tenaga kesehatan dan distribusi yang tidak merata, faktor kualitas, pemerataan dan keterjangkauan pelayanan kesehatan juga menjadi salah satu faktor tingginya utilisasi persalinan di Provinsi Bengkulu. Meskipun sudah terdapat RS di setiap Kabupaten, namun kualitas pelayanan juga masih rendah. Provinsi Bengkulu baru memiliki RS 2 RS tipe B milik Pemerintah Provinsi Bengkulu, 13 RS tipe C dan 8 RS Tipe D (Antoni, 2020). Upaya yang harus dilakukan oleh pembuat kebijakan untuk memastikan bahwa setiap area/wilayah menerima pelayanan kesehatan yang berkualitas sesuai dengan kebutuhan adalah mengalokasikan sumber daya kesehatan terdistribusi ke wilayah sesuai dengan jumlah populasi, faktor biaya input (tenaga kerja dan modal) maupun needs.

Kesenjangan faskes maupun tenaga kesehatan di Provinsi Bengkulu perlu segera diupayakan perbaikan dalam peningkatan pelayanan kesehatan. Pemerintah Daerah perlu meningkatkan anggaran kesehatan sesuai amanat undang-undang dan melakukan peningkatan pelayanan kesehatan dalam hal penyediaan fasilitas pelayanan kesehatan, pemenuhan standar pelayanan minimal, dan peningkatan mutu layanan. Standarisasi teknis pelayanan menjadi sangat penting dalam penyediaan pelayanan kesehatan disamping kontrol biaya dalam pelayanan kesehatan agar tujuan rumah sakit dapat berjalan seefisien mungkin.

Lebih jauh, pandemi COVID-19 berpotensi meningkatkan ketimpangan akses dan pemanfaatan layanan operasi caesar saat ini. Laporan WHO 2021 mengindikasikan bahwa angka operasi caesar akan tetap meningkat selama pandemi (WHO, 2021). Namun belum diketahui dari golongan ibu hamil terjadi peningkatan pemanfaatan layanan prosedur caesar. Sebagaimana dilansir dalam berbagai penelitian bahwa golongan termiskin, dan hampir miskin adalah golongan yang paling terdampak dari pandemic COVID-19 secara sosial ekonomi (Samudra \& Setyonaluri, 2020). Melihat hasil SUSENAS 2018, masih ada beberapa kabupaten di provinsi Bengkulu, seperti Bengkulu Tengah, Lebong, Bengkulu Utara dengan proporsi lebih dari $40 \%$ rumah tangga yang termasuk kelompok $20 \%$ termiskin yang belum terdaftar dalam program JKN, ada kemungkinan ibu hamil dari golongan ini yang seharusnya membutuhkan SC tidak dapat mengakses pelayanan ini.

Selain terbatasnya jumlah tenaga kesehatan dan distribusinya yang tidak merata faktor yang menyebabkan tingginya utilisasi persalinan SC di Provinsi Bengkulu adalah faktor mutu kualitas pelayanan. Hambatan utama layanan kesehatan yang berkualitas adalah adanya financial barriers. Mutu kualitas merupakan salah satu konsep inequity dalam pelayanan kesehatan (Goddard \& Smith, 2001). Kualitas pelayanan meliputi isu dalam ketepatan pemberian pelayanan kesehatan baik dalam aspek medis maupun non medis. Apakah tindakan SC dilakukan atas indikasi medis atau bukan. Hasil penelusuran tingginya kasus SC dikarenakan indikasi medis berupa tindakan sectio pada 
kehamilan pertama, tapi untuk menentukan SC tersebut atas permintaan sendiri atau indikasi medis itu menjadi tantangan besar tersendiri (Novelia, 2021). Oleh karena itu menjamin ketepatan tindakan medis telah sesuai diberikan menurut kebutuhan maka Tim Kendali Mutu dan Kendali Biaya perlu melakukan audit medis dan atau audit klinis.

Ketidakmerataan ketersediaan fasilitas kesehatan, tenaga kesehatan dan kondisi grafis yang sangat bervariasi, menimbulkan potensi melebarnya ketidakadilan kesehatan antar kelompok masyarakat (Misnaniarti, Hidayat, \& et.al, 2018). Pemerintah Provinsi Bengkulu dan BPJS Kesehatan perlu duduk bersama membagi tanggung jawab dalam pengawasan dan peningkatan pelayanan SC. Hal ini dimaksudkan meminimalisir moral hazard dalam penggunaan dana JKN. Dashboard JKN yang telah dikembangkan BPJS Kesehatan tahun 2020 diharapkan dapat menjadi media transfer informasi dan data untuk keterbukaan dan transparansi kebijakan JKN untuk layanan SC.

DJSN yang memiliki fungsi monitoring dan evaluasi perlu mengkaji secara mendalam dan holistik mekanisme pemenuhan kompensasi sebagaimana yang diamanatkan dalam UU SJSN khusus untuk layanan SC bagi wilayah kabupaten-kabupaten di Provinsi Bengkulu yang belum memiliki fasilitas kesehatan memadai. Mengingat Provinsi Bengkulu masih tergantung pada anggaran pusat, kebijakan kompensasi perlu dirumuskan secara integratif dengan program afirmasi kesehatan yang dibuat oleh pemerintah pusat.

\section{Kesimpulan dan Saran \\ Kesimpulan}

Tata kelola program JKN di Provinsi Bengkulu sudah cukup baik dalam aspek capaian kepesertaan. Namun, pada pemerataan pelayanan dibutuhkan keterbukaan dan sinergitas program dan kebijakan antara pemerintah Provinsi
Bengkulu dan BPJS Kesehatan. Layanan SC di Provinsi Bengkulu belum merata dan berkeadilan. Utilisasi layanan operasi SC lebih banyak dinikmati oleh penduduk yang tinggal di Kota Bengkulu dan didominasi segmen kepesertaan mampu yakni PPU (39\%) dan PBPU (45\%). Masih terdapat disparitas baik kuantitas maupun kualitas atas ketersediaan fasilitas dan tenaga kesehatan yang lebih banyak tersebar di Perkotaan dibandingkan di Kabupaten.

\section{Saran}

Pemerintah Kabupaten mengupayakan penyusunan kebijakan dalam pemenuhan akses dan kualitas layanan SC salah satunya dengan pemenuhan dokter Spog di wilayah kabupaten yang belum memadai.

BPJS Kesehatan menginisiasi audit medis melalui tim independen untuk memastikan bahwa tindakan SC dilakukan karena adanya indikasi medis.

\section{Daftar Pustaka}

Antoni, H. (2020). Evaluasi Capaian Kepesertaan, Pemerataan dan Mutu Pelayanan Kesehatan Program JKN di Provinsi Bengkulu. Bengkulu.

Ayuningtyas, D., \& et.al. (2018). Etika Kesehatan

Pada Persalinan Melalui Sectio Caesarea

Tanpa Indikasi Medis. Jurnal MKMI, 9-16.

Berita Satu. (2020). Pemprov Bengkulu Alokasikan Rp 17,6 Miliar untuk Subsidi BPJS. Retrieved from https://www.beritasatu.com/nasional/6901 55/pemprov-bengkulu-alokasikan-rp-176miliar-untuk-subsidi-bpjs

BPJS Kesehatan. (2018). Laporan Pengelolaan Program dan Laporan Keuangan Jaminan Sosial Kesehatan Tahun 2017. Jakarta.

BPJS Kesehatan. (2020). Kendali Mutu dan Biaya Jamin Keberlangsungan JKN KIS. Retrieved from https://www.bpjs- 
kesehatan.go.id/bpjs/dmdocuments/2981b

8067b00bdaf6e562e8b507124b7.pdf

DaSK. (2021). Data Sampel BPJS 2015-2018.

Retrieved from https://pkmkugm.shinyapps.io/BPJSdataExplorer/

Delport, S. (2019, Juni 17). Global epidemiology of use of and disparities in caesarean sections. http://ees.elsevier.com/ thelancet/.

DJSN. (2021). Retrieved from http://sismonev.djsn.go.id/

Dong, E., Xu, J., Sun, X., Zhang , L., \& Wang, T. (2021). Differencen in regional distribution and inequality in health resource allocation on institutions, beds, and workforce:a longitudinal study in China . BMC, 1-11.

Goddard, M., \& Smith, P. (2001). Equity of access to health care services: Theory andevidence from the UK. Social Science \& Medicine, 53(9), $1149^{2} 1162$. DOI:10.1016/S0277-9536(00)00415-9.

Kemenkeu. (2019). Retrieved from https://djpb.kemenkeu.go.id/portal/images /file_artikel/file_pdf/kfr/smst22018/09_kf r_smst22018_bengkulu.pdf

Luna, A. J., Kruchten, P., \& Moura, H. P. (2015). Agile Governance Theory: conceptual development. International conference on Management of Technololgy and Information System, (pp. 1-22). Sao Paolo.

Mishra, P. S., Veerapandian, K., \& Choudhary, P. K. (2021). Impact of Socio Economic inequity in access to maternal health benefits in India: Evidance form Janai SurakshaYojana using NFHS data. Plos ONe, 1-17.

Misnaniarti, Hidayat, B., \& et.al. (2018). Ketersediaan Fasilitas dan Tenaga Kesehatan Dalam Mendukung Cakupan Semesta Jaminan Kesehatan Nasional. Jurnal Penelitian dan Pengembangan Pelayanan Kesehatan, 6-16.
Nababan, H. Y., Hasan, M., Marthias, T., \& et.al. (2018). Trends and inequities in use of maternal health care services in Indonesia 1986-2012. International Journal of Women's Health, 11-24.

Novelia, E. (2021, https://www.youtube.com/watch?v=eLov MnNW1sQ). Penggunaan APBN dan BPJS kesehatan dalam Prospek Keadilan Sosial: Studi Kasus PBI APBN, Defisit dan Pengeluaran untuk Penyakit Jantung, Cancer dan SC. Yogyakarta.

Putri, A. E. (2015). Paham JKN: Jaminan Kesehatan Nasional. Jakarta: CV Komunitas Pejaten Mediatama.

Samudra, R., \& Setyonaluri, R. (2020). Inequitable Impact of COVID-19 in Indonesia: Evidence and Policy Response. https://en.unesco.org/inclusivepolicylab/si tes/default/files/analytics/document/2020/ 9/200825_Policy Report_Inequitable Impact of COVID 19 in Indonesia.pdf, 15.

Susenas. (2018). Retrieved from https://daskbaru.net/capaian-equity-jaminankesehatan-nasional-jkn/

Trisnantoro, L., \& et.al. (2019). Apa Opsi-Opsi Kebijakan JKN Saat Ini? Sebuah Analisis Kebijakan JKN dalam Perspektif Pemerataan Pelayanan Kesehatan Berkeadilan, Bermutu dan Berkelanjutan. Retrieved Mei 01, 2021, from https://drive.google.com/file/d/1tuPAut3K ZWdlWBGSmk7FtLrmvT6R-R9o/view

WHO. (2021). Caesarean section rates continue to rise, amid growing inequalities in access : WHO Rising rates suggest increasing numbers of medically. https://www.who.int/news/item/16-06-

2021-caesarean-section-rates-continueto-rise-amid-growing-inequalities-inaccess-who, 5-9.

Widjayanti, T. B., \& Sjaaf, A. (2020). Characteristics Sectio Caesaria Under 
National Health Insurance Programm at The Non Profit Refferal Hospital in Jakarta. Indian Journal of Public Health Research \& Development, 359-363.
Zahroh. (2020). Trends and sociodemographic inequalities in the use of caesarean sectio in Indonesia 1987-2017. BMJ Global Health 